\title{
Religious Institutions in Japan Responding to Covid-19-Induced Risk and Uncertainty
}

Some Preliminary Considerations

\author{
Paola Cavaliere \\ Osaka University, Osaka, Japan \\ pcavaliere@hus.osaka-u.ac.jp
}

\begin{abstract}
This paper discusses adaptations and alternatives that religious institutions in Japan have formulated to help communities develop the capacity to cope with the crisis and perceived risk generated by Covid-19. Qualitative data and observations of online information were collected between February and June 2020. Guided by a crisis approach, the study explores inward and outward responses that some Japanese religious institutions and their members have enacted. The investigation uses Douglas' (1994) interpretative model of risk and explores those "thought-styles" that religious institutions have engendered that are conducive to cohesion and stability. Findings show that established and new religions alike swiftly responded to Covid-19-induced safety measures by embracing digital technology to continue their core function as cohesion-providers for their social and spiritual communities. The analysis shows that adjustments toward disembodied religious practices might hold potential to continue beyond current Covid-19-related social restrictions.
\end{abstract}

\section{Keywords}

Covid-19 - Japanese religions - risk theory - Mary Douglas

Between February and April 2020, around the time when the Covid-19 (severe acute respiratory syndrome coronavirus 2-SARS-CoV-2) pandemic was at its height in Europe, three major Abrahamic religious traditions (Christianity, Islam and Judaism) were preparing for several annual and very public sacred celebrations. Jews were approaching Passover; Christians were getting ready 
for Easter; and Muslims were about to begin ritual practices tied to Ramadan and the upcoming Hajj. With the World Health Organization (wHo)'s declaration of the state of pandemic on 11 March 2020 (WHO 202Oa), Jewish, Christian and Muslim religious communities had no option but to dramatically downscale or voluntarily cancel all those celebrations that involved family and communal gatherings. The wHO would later issue specific guidelines addressing religious communities and their leaders so that they would implement safe practices and educate their adherents about Covid-19 prevention measures. These "Practical considerations for faith-based communities and their leaders" (WHO 2O2Ob) range from a general call for social distancing to specific directives on how to restrict contact with devotional objects, reduce or cancel worship rituals and refrain from communal embodied practices such as the ablution or hand and foot washing (WHO 2O2ob: 2).

Since major popular celebrations in the Japanese calendar occur at the beginning of the year-with visits to the local temples or shrines (hatsumōde 初 詣)—and in mid-August for the obon お盆 festival commemorating the ancestors, there was no pressing reason for Japanese official agencies to translate and circulate the wHo guidelines to religious communities in Japan. ${ }^{1}$ Nevertheless, throughout the year, most Japanese participate in numerous religious-related collective rituals and events anchored to a shared understanding of folk beliefs, traditional Buddhist doctrines, and Shintō 神道 collective rituals (Cavaliere 2019a). However, a constitution that tightly restricts state intervention in religion disincentives government leaders and official agencies to cater to religious interests.

In this context, when the Covid-19-hit Diamond Princess cruise ship was quarantined at Yokohama port on 3 February 2020, temples and shrines around Japan were not cautioned against the dangers of significant virus transmission rate at collective religious-related cultural events. Hence, celebrations of the coming of spring in the bean-throwing setsubun 節分 festival scheduled on 3 February were carried out nationwide with no restrictions and limited concern. This ritual is held to welcome spring by throwing roasted soybeans (mamemaki 豆まき) while chanting “oni wa soto, fuku wa uchi” 鬼は外福は内 (demons out, good fortune in) to drive away winter's evil spirits that bring disasters and diseases. On that day, Jalan.net, a popular online travel agency, added a banner on the top of its " 72 best setsubun events nationwide in 2020" webpage

1 The government-sponsored Nihon Shūkyō Renmei 日本宗教連盟 (Japanese Association of Religious Organizations) published a document online on 24 April 2020 addressing practices of religious communities. It does not refer to the wHo guidelines. See https://www.bunka.go .jp/koho_hodo_oshirase/sonota_oshirase/pdf/20200424170o_o1.pdf (accessed 25June 2020). 
informing viewers of possible disruptions because of the novel coronavirus. ${ }^{2}$ Given the essential, symbolic nature of such collective ritual, many participants saw in its purifying power a proper way to drive the threat of Covid-19 away. Kiyomi (41), an occasional temple-goer who attended the Dōjima Setsubun Omizukumi Matsuri 堂島節分お水汲みまつり in Osaka with her two daughters, commented: "I hope these beans and the amulet I bought can protect my family from the coronavirus" (conversation held on 3 February 2020). ${ }^{3}$ Despite the reliance on scientific approaches implied by her career as a biologist, Kiyomi does not dismiss the symbolic-magic power of such collective rituals, which help her neutralize her fears of the coronavirus, at least to some extent.

Given the popularity of the setsubun festival, several media companies offered free digital content to view major events around Japan. NHK (Japan Broadcasting Corporation), the newspaper MainichiShinbun 毎日新聞 and the leading news agency Kyōdō Tsüshinsha 共同通信社 (Kyodo News), for example, live-streamed Naritasan Shinshōji's 成田山新勝寺 event nationwide. ${ }^{4}$ According to the above-mentioned Jalan.net webpage, Naritasan Shinshōji temple in Narita city, Chiba Prefecture, is one of the top destinations for the setsubun celebration. The temple has built its reputation over the years thanks to the presence of famous sumo $\bar{o}$ 相撲 wrestlers, television talents and film actors who help during the ceremony. On 3 February 2020, several top ranking sumō wrestlers, including yokozuna Hakuhō 白鵬, and famous actors such as Hasegawa Hiroki 長谷川博己, Kadowaki Mugi 門脇麦 and Motoki Masahiro 本木雅弘 from the NH K historical drama Kirin ga kuru 麒麟がくる (Awaiting Kirin), helped throw 86o kilograms of soybeans and 400 kilograms of unshelled peanuts. ${ }^{5}$ Three hundred and sixty-six amulets were also tossed into a crowd of thousands of people assisting the ceremony on that day, ${ }^{6}$ while praying for the end of the coronavirus. $^{7}$

Around the time when adults and children were experiencing the cathartic multisensory experience of the setsubun ritual, an online movement started popularizing the illustration of Amabie アマビエ, a kind of yōkai 妖怪, or

2 See https://www.jalan.net/news/article/418235/(accessed 3 February 2020).

3 Japanese to English translations of qualitative data in this paper are by the author.

4 See https://www.naritasan.or.jp/2020/02/04/14819/. See also https://mainichi.jp/articles/202 00203/koo/oom/04o/13200oc; for Kyodo News see https://www.youtube.com/watch?v=q2C -XpfxpuU (accessed 3 February 2020).

5 See https://www.naritasan.or.jp/gyoji/setsubun-e/ (accessed 3 February 2020).

6 See https://www.naritasan.or.jp/gyoji/setsubun-e/ (accessed 3 February 2020).

7 See https://www.nikkei.com/article/DGXMZO55091120R3oC20A1MLoooo/ (accessed 3 February 2020). 
demonic spirit, which is believed to have the power to ward off pestilence and, therefore, could help fight against the novel coronavirus strain. According to a popular belief, in Japan's Edo period (1603-1868), the mermaid-like yōkai emerged from the sea off the Higo domain, now Kumamoto Prefecture, and told locals that they should draw a picture of it and ask others to do the same in the event of a plague. For much of the past two centuries, the legend of Amabie remained rather dormant, except for some modern illustrations by yōkai specialists, such as Yūmoto Kōichi 湯本豪一. ${ }^{8}$ However, with mounting news of spiking numbers of Covid-19 cases around the world and within the Diamond Princess cruise ship quarantined at Yokohama port, the compassionate yōkai Amabie resurfaced on social media, reviving hopes that its power would ward off the infectious disease.

In February 2020, the hashtag \#amabie and its English version \#amabiechallenge went viral, ${ }^{9}$ with people posting their drawings, paintings and personalized depictions of Amabie. Its image soon started appearing on cookies, facemasks, candies, bread rolls, toys and school lunch sets. From mid-March to 6 June 2020, Hirota Jinja 廣田神社 in Hyōgo prefecture distributed almost 30,ooo hand-made Amabie paper amulets ( $g \circ f u$ 護符) at no cost. ${ }^{10}$ Eventually, the Amabie social phenomenon drew the attention of Japan's Ministry of Health, Labor and Welfare. After the wHO cautioned the young population around the world not to underestimate the impact of Covid-19 on people of young age, ${ }^{11}$ the Japanese ministry decided to initiate an awareness campaign to spread the same message. The purpose was to educate Japanese youth about the new strain of coronavirus and the measures they should take (MHLW 2020a). Given the popularity of Amabie among internet users and consumers, the ministry decided to make it the logo of its public safety campaign targeting the youth.

British anthropologist Mary Douglas suggests that observing how people respond to a crisis generally shows that there is a fixed repertoire of possible answers, which the scholar calls "thought-styles," among which "a plausible

8 Yūmoto Kōichi is the director of the Miyoshi Mononoke Myūjiamu 三次もののけミュー ジアム (Miyoshi Mononoke Museum) in Miyoshi city, Hiroshima Prefecture. The museum displays the largest collection of yōkai illustrations and related objects in Japan. See https://miyoshi-mononoke.jp/introduction/introduction-yumoto/ (accessed 25 June 2020).

9 For the hashtag \#amabie see https://twitter.com/hashtag/アマビエ. For \#amabiechallenge see https://twitter.com/hashtag/amabiechallenge (accessed 20 June 2020).

10 See http://www.hirotahonsya.or.jp/index.html (accessed 20 June 2020).

11 See the twitter by wHO director-general available at https://twitter.com/drtedros/status/ 1241095750492323840 (accessed 21 March 2020). 


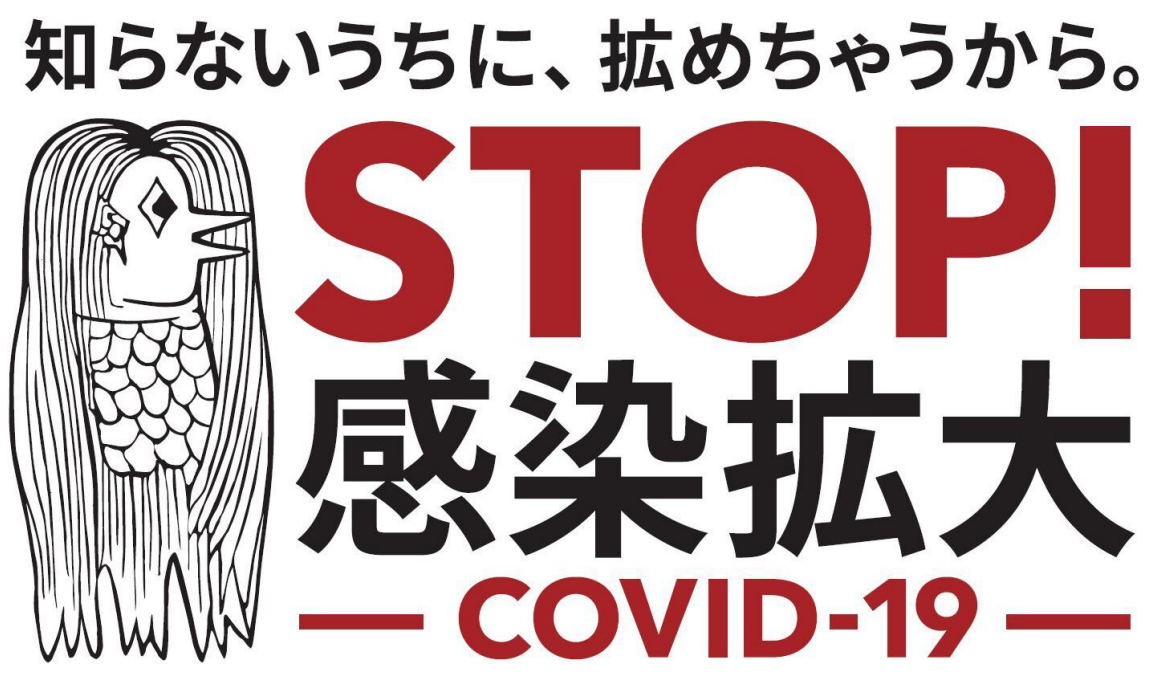

FIGURE 1 Covid-19 related campaign with amabie logo. Japanese Ministry of Health, Labor and Welfare

HTTPS://WWW.MHLW.GO.JP/CONTENT/1090000o/0oo619811.JPG (ACCESSED 20 JUNE 2O2O)

explanation is chosen, and a fixed repertoire of obligatory actions follow on the choice" (Douglas 1994: 211, 5). According to Douglas, when a community articulates and communicates about a crisis or disastrous event through shared and comprehensible symbolic structures, they become able to develop a consensus on the kinds of solidarity that will support them to cope collectively with the event and the crisis (Douglas 1994: 30). In her analysis of risk, Douglas suggests that once the community has agreed on shared cosmological beliefs, individuals tend to transfer decision-making that would help them cope with risk to institutions that are, explicitly or latently, attributed to managing, maintaining and regulating such belief systems (Douglas 1994: 71-78). This, in turn, creates an "extra degree of coherence between institutions, beliefs, and actions [that] will reinforce stability" (Douglas 1994: 79). The two examples mentioned above give us a sense of the interpretative repertoire and type of actions a large number of Japanese draw upon to respond to the pandemic.

This paper builds on Douglas' methodological point that "there is no way of proceeding with analysing risk perception without typifying kinds of communities according to the support their members give to authority, commitment, boundaries, and structure" (Douglas 1994: 47). Following Douglas' recommendation of observing specific micro and macro capacities, this study will evaluate how religious communities have contributed to the management of the crisis. The method used in this study is both descriptive and qualitative, draw- 
ing upon data derived from email exchanges or conversations held by phone or over Zoom meetings with members of religious organizations. These are integrated with observations of online information available at the time of writing (March to June 2020). This paper will provide examples from established religions such as Buddhist temples and Shintō shrines; four new religious movements (Sōka Gakkai 創価学会, Risshō kōseikai 立正佼成会, Tenrikyō 天 理教 and GLA ジー・エル・エー); and two Christian denominations, the Roman Catholic Church and the United Church of Christ in Japan.

A methodological consideration requires acknowledgment at this point. This work utilizes few selected cases of Japanese established and new religions as a source of observational and qualitative data to get an understanding of responses and adjustments that religious institutions have enacted in this country. I am aware that obtaining more varied qualitative data would provide information that may be more representative of the general population. However, given the time and restrictions imposed in response to the Covid-19 pandemic, any form of extended in-person fieldwork activity was halted. For this particular inquiry, therefore, I have depended on "theoretical sampling" (Reid 1991: 123) to collect indications of a general trend in inward and outward responses from religious institutions that inform us about an attitude toward adaptations of the religious-cultural framework, individuals' approach to it, and their interrelationship with everyday practice.

On these premises, a "crisis approach" (Arjen et al. 2007) may help discern the strategies that individuals and institutions have been utilizing to make sense of a situation of confusion and isolation. According to this framework, crisis is made up of three components: threat, uncertainty and urgency (Arjen et al. 2007: 23). The focus of this study will be less on the threat and vulnerability aspects than on the resulting responses engendered by the uncertainty and urgency of the Covid-19 pandemic. Filtering socio-cultural experiences through the lens of how the crisis has been challenged and what strategies have been enacted to advert it, may help us see the crisis in a different light. Specifically, the study will focus on ways in which uncertainty and urgency have created opportunities for members of religious communities and their leaders to challenge the perception of risk and vulnerability that accompanies it. This concerns the strategies and resilient capacity of religious communities in Japan, which activate certain social protections in order to overcome adverse situations affecting people's well-being.

Observations will also attempt to identify what shifts are happening during this unique time of crisis and will provide provisional considerations on how this might influence the Japanese's socio-cultural understanding of religion and practice in the future. With temples, shrines and churches in Japan dramat- 
ically downsizing or cancelling religious-related collective events, ceremonies and rituals under the Covid-19 distancing measures, one wonders what cosmological beliefs and related collective religious-cultural events providing repertoires of possible answers (Douglas 1994: 5) could be articulated to help cope collectively with the crisis. What adaptations or alternatives have providers of such repertoires formulated to help communities develop the capacity to cope with both the crisis and risk generated by Covid-19? How have local religious communities been responding to social-distancing and stay-at-home restrictions that affect individual and collective rituals and, as a consequence, their resilient capacity of neutralizing worries and threat?

In order to address these research questions, in the following section I will first offer some factual information related to Covid-19 in Japan, which will help contextualize the methodology framing this study. This will be followed by two sections giving insights into inward and outward religious institutional responses, with qualitative examples from both established and new religions in Japan. It will also include instances on how individuals have contributed to adjusting and creating new religious-cultural repertoires, symbolic meanings, rituals and habits to cope with the Covid-19-driven sense of risk and uncertainty. As such, this study will attempt to contribute to a larger debate regarding the impact of Covid-19 on religious institutions and their social role during this exceptional time, shading some light on to what key urgencies Japanese religious organizations and communities have been responding to.

\section{Mapping Out Religion and Covid-19 in Japan: Factual Considerations}

In less than two months, from 15 January 2020 - when the first case of Covid19 was confirmed - to 1 March, Japan counted 817 infected cases and a total of 31 deaths (M HLW 2020b:1). These figures, which did not include the number of patients on charter flights and cruise ships, were mostly related to clusters in live music clubs (Osaka and Hokkaido), sport facilities (Tokyo, Aichi prefecture and Chiba Prefecture) and welfare facilities (Hyogo and Kanagawa prefecture) (MHLW 2020b: 5). As of 17 March 2020, however, the situation was escalating with 2,229 infected cases and a crucial $40.6 \%$ of confirmed infected people with unknown routes of transmission (M HLW 202OC: 1), meaning that in addition to known clusters, the risk of infection was getting out of control and was reaching the larger population. On 6 April 2020 the number of reported cases jumped to 3,906, showing that the doubling time (the time required for the number of infections to double) was shortening to less than 4 days (MHLW 2020d: 3). 
Given the major risk of straining the medical health system-unprepared to respond to an epidemic of this nature and scale - on 7 April 2020 the Japanese government declared a state of emergency in Saitama, Chiba, Tokyo, Kanagawa, Osaka, Hyōgo, and Fukuoka (Kantei 2020a).

With mounting concern about the impact of the upcoming week-long spring Golden Week holiday (from 30 April to 5 May 2020), which usually sees a large number of people travelling across the country and abroad, the government launched the "8wari gen" 8割減 (80\% down) campaign, with the purpose of reducing foot traffic at major train stations and other alert areas of down to $80 \%$ as compared to previous years' Golden Week (Kantei 2020b). On 5 May 2020 the Japanese government extended the state of emergency nationwide to the end of May, imposing travel, movement and gathering restrictions and encouraging "self-restraint" (jishuku 自肃) while also inviting the working population and companies to an unprecedented shift to teleworking (M HLW 2O2Oc: 3). It also urged a calm response to the state of emergency in order to prevent panic buying of food, medicine and daily necessities. While the state of emergency was lifted on 25 May after a fall in coronavirus cases (MHLW 2O2Oe), the government reinstated the restriction on non-essential gatherings and urged residents to establish an atarashii nichijo 新しい日常 (new normal) by implementing the 3 Cs: avoiding closed spaces, crowded places, and close contact (MHLW 2020C: 3).

Although the number of deaths and infected cases in Japan has been far lower than figures seen, for example, in Italy around the same time (wHO 2020c: 4), the socio-economic impact of the Covid-19 pandemic and related emergency measures that have been enacted can be compared to that of a disaster event on national scale. Unsurprisingly, the Japanese media use the term korona-ka コロナ禍 (coronavirus disaster) to refer to the Covid-19 situation in Japan. From a sociological perspective, a disaster is an event affecting an entire society or some subdivisions wherein "essential functions of the society [are] prevented" (Fritz 1961: 655). From a sociological view of religion, the Covid-19-imposed isolation and social distance decimated the Durkheimian idea of functional religion, with its primary role of provider of social integration, solace, security through the collective cultural effervescences that deliver solutions to individual vulnerabilities. The extent of such a disaster evokes a deep sense of crisis in which values of safety, security and solace for oneself and one's loved ones, all deeply embedded in the routine practices and beliefs provided by institutions, come under threat. In sociological terms, this happens when our "thought-styles" (Douglas 1994: 211) are disrupted because the ways of thinking and use of categories that are rooted in institutional dynamics and everyday interaction rituals are compromised to a critical point. Two 
weeks after the cancellation of Tokyo 2020 Olympics on 24 March (Kantei 2020c) - the most long-awaited event of the year-the declaration of the state of emergency wiped away in a domino effect the most important large scale religious-based socio-cultural rituals and events: the grand sumō tournament in May; Gion Matsuri 祇園祭 in Kyoto, the Awa Odori 阿波踊り dance festival in Tokushima and the Tanabata 七夕 celebrations in July; and most collective ancestors' commemorations of the obon in August, to name but a few. ${ }^{12}$

As it happens, the pandemic has had a highly disruptive impact on activities of temples, shrines and religious communities that are crucial institutions providing the population with the diffused thought-styles it needs to creates the necessary "coherence between institutions, beliefs, and actions [that] will reinforce stability" (Douglas 1994: 79). Although Abrahamic religions and their major annual celebrations between February and April are not part of the religious landscape of Japan - therefore exempting it from disruptions on major religious-cultural events related to those religious traditions-Japanese religious organizations are still vicariously required to manage collectively understood beliefs, rituals and symbolic structures (Davie 2007; 2010) that pervade Japanese people's everyday life. While identifying themselves as mushūkyō 無 宗教, non-religious (Cavaliere 2019a: 4-6), most Japanese people participate in several religious-based cultural events and festivals throughout the year (NHK 2019). As such, religious organizations hold the potential to engender the needed Douglasian stability to cope with crisis and respond to newer sources of risk and uncertainty such as that induced by the Covid-19.

\section{Religions' Inward Responses}

\section{Established Religions Embracing Technology: Re-sacralization} in a Time of the Pandemic

One of the most interesting adaptions to observe over the first three months of the pandemic in Japan (February to May 2020) was the way in which traditional religious institutions swiftly responded to social distancing measures by embracing digital technology in order to continue what they saw as their core functions as religious communities. Temples, shrines and churches in Japan

12 Admittedly, one should also look into other secular interaction rituals that provide the Douglasian cultural sense of coherence between institutions, beliefs, and actions that reinforce stability. For example, the beginning of the professional baseball and football seasons in April and Japan's famed summer high school baseball tournament Kōshien 甲 子園 in June are such key events. 
that have traditionally relied on collective rituals and worship promptly transitioned from face-to-face to online forms of meeting. The main purpose of such swift action was to guarantee a minimum level of institutional response to both usual and new demands of people looking for spiritual relief and religious commodities that would help them cope with the emotional distress of the pandemic.

From 24 April to 31 May, Tōdaiji 東大寺 temple in Nara, a World Heritage site as well as a popular devotional and tourist destination, closed access to its Nandaimon 南大門 (Great South Gate) and the Daibutsuden 大仏殿 (Great Buddha Hall), home to the $15 \mathrm{~m}$ high statue of Daibutsu, the Buddha Vairocana. Completed in $75^{2}$ in the aftermath of several crop failures and a devastating smallpox epidemic, the Daibutsu represents the belief in Buddha Vairocana's power to protect Japan from infectious diseases. Given its symbolism, the temple decided to open the large front window so that the face of the Great Buddha could be seen from the outside. The window is usually open only about ten days a year, during the obon festival in August and around the New Year's Day. In this respect, the over-a-month long window opening during the pandemic was an exceptional event. On the Tödaiji temple website, virtual visitors could read that:

prayers are always with the Great Buddha during difficult times. The temple is supposed to be a place open to people, for them to visit and pray at any time. Therefore, we will not completely close our gates. We believe that it is time for us to put our efforts into global cooperation and efforts towards ending the epidemic. ${ }^{13}$

In response to the stay-home measure, the temple also set a 24-hour video livestream of the statue and of the main hall in order to allow people to view the Great Buddha remotely. ${ }^{14}$ The website niconico ニコニコ Live Broadcasting, which hosted the live streaming, reads that it would "broadcast the Great Buddha of Tōdaiji Temple and the worship services held there to pray for the end of the epidemic for as long as possible." As of 28 May 2020 the statue had 317,110 views and 117,942 posts. ${ }^{15}$ Topics varied from concerns about Covid-19 (referred to as "19" in the blog) to the yellow sand storms and the first typhoon expected to approach Japan by the end of May. "Please Buddha let us be spared from

13 See http://www.todaiji.or.jp/ (accessed 13 May 2020).

14 See https://live2.niCovideo.jp/watch/lv325443328 (accessed 28 May 2020).

15 See https://live2.niCovideo.jp/watch/lv325853959?ref=watch_rec (accessed 28 May 2020). 


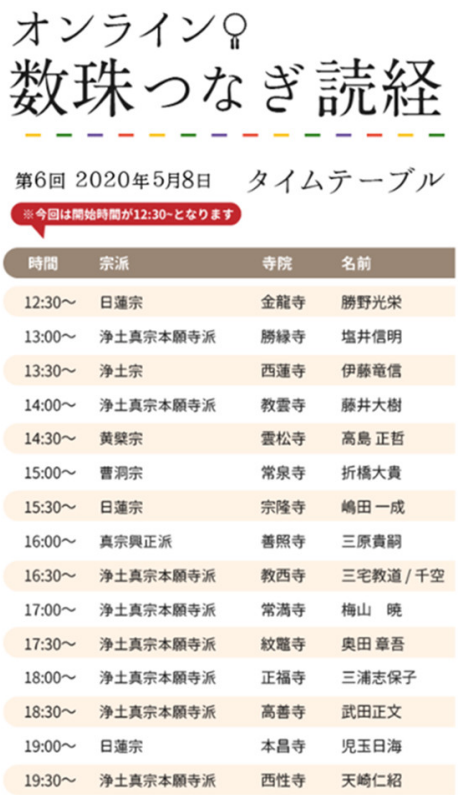

FIGURE 2

A daily schedule of the "Reading Sutra Online" HTTPS://WWW.FACEBOOK.COM/READINGSUTRAS .ONLINE/ (ACCESSED 13 MAY 2O2O)

further hardships" (kore ijō no kunan wa go yōsha kudasai hotoke samaこれ以 上の苦難はご容赦ください仏様) reads a representative comment.

Under the stay-home measure, various Japanese Buddhist schools of different sects reunited into a digital community called o-uchi de otera お家でお 寺 (Buddhism at home) ${ }^{16}$ sponsoring the Facebook account "Reading sutras online” (onrain juzu tsunagi dokyō オンライン数珠つなぎ読経) ${ }^{17}$ where monks from all over Japan took turns reciting sutras and prayers online at scheduled times.

The online social movement $o$-uchi de otera had its Shintō equivalent in the Twitter-based o-uchi de jinja お家で神社 (Shintō at home). ${ }^{18}$ Onoterusaki Jinja 小野輝先神社 in Tokyo, for example, offered onrain sanpai オンライン参择 (online praying) and gave instructions on how to perform prayers at home. ${ }^{19}$

16 See http://readingsutras.online/schedule/20200508/ (accessed 13 May 2020).

17 See https://www.facebook.com/readingsutras.online/ (accessed 13 May 2020).

18 See https://twitter.com/hashtag/\% $/ \mathrm{E}_{3} \% 81 \% 8 \mathrm{~A} \% \mathrm{E}_{3} \% 81 \% 86 \% \mathrm{E}_{3} \% 81 \% \mathrm{Al}_{1} \% \mathrm{E}_{7} \% \mathrm{~A}_{5} \%{ }_{9} \mathrm{E}$ $\% \mathrm{E}_{7} \% \mathrm{~A}_{4} \% \mathrm{BE}$ (accessed 20 June 2020).

19 Onoterusaki Jinja's instructions for online praying read as follows: Step one: Make your wish from home: You can make a vow or a request to the shrine. Look inside yourself and fill your heart with your wish. Step two. Share the votive ema tablet with your own wish: A wish is also a commitment to pursue your goal. Please share your wish on SNs. Step three. Watch the live prayers: Priests will take care of your prayers. Watch them praying and focus 


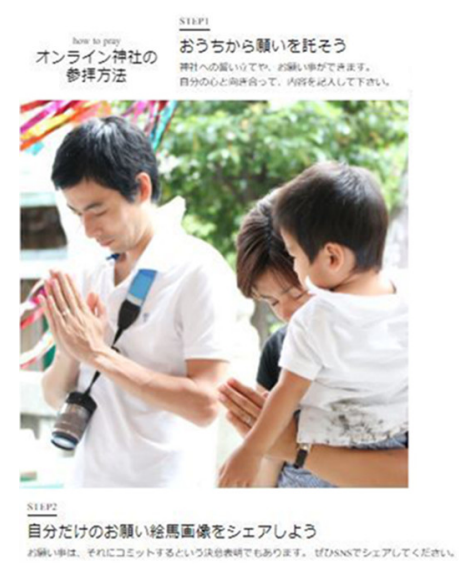

\author{
FIGURE 3 \\ Onoterusaki Jinja's instructions for online praying \\ HTTP://ONOTERU.OR.JP/ONLINE (ACCESSED 21 MAY \\ 2020)
}

The shrine also offered a choice of three virtual ema 絵馬 (votive tablets) that online visitors could use for their prayers. Each ema is inscribed with a specific plea: 1. "Safe commuting and work: I pray to be protected from being infected by Covid-19 while commuting to work or at the workplace;" 2. "Praying for a swift end of the Covid-19 pandemic: I pray for an immediate return to normal life with a smile as soon as possible;" 3. "Family safety: I pray for my partner, my family and myself to stay healthy without being affected by Covid-19 and for a swift end of the pandemic."20 The numerous comments on the shrine's Twitter account reveal the success of the online modality.

Given the jishuku (self-restraint) measures in place, more and more shrines and temples moved their services online, offering to send their votive seal stamps electronically or by post. For example, Katori Jinja 香取神社 in Saitama prefecture, a very popular shrine among mothers-to-be for its effective omamori お守り for rapid and safe delivery for mothers and babies, has provided a very successful mail service during the emergency, offering a delivery of charms and other amulets upon request by email or phone. ${ }^{21}$

With people's limited freedom to visit worship places in person, some temples moved their objects of devotion outside their buildings and precincts to allow individuals to pay their devotion without having to go inside. Ishiya-

on yourself. Let's pray for an early end of the pandemic. Step four: Get a special shuin 朱印: at the end of the session, you will receive a virtual image of the seal stamp of our shrine. One day, when it is safe to visit the shrine, you will be able to exchange this virtual stamp with a paper seal stamp. See http://onoteru.or.jp/online (accessed 21 May 2020).

20 See http://onoteru.or.jp/online (accessed 21 May 2020).

21 See https://katorijinja.com/ (accessed 23 May 2020). 
madera 石山寺 in the city of Ōtsu, Shiga Prefecture, decided to display their 5 -meter high statue of a ao oni 青鬼 (blue demon) in the public park in front of the temple to allow passers-by to pray to this figure without having to go inside the temple. The blue demon, which is said to represent Ishiyamadera temple's founder who became a demon after death and swore to protect both its temple and the community, is usually displayed in the temple grounds during the popular ao oni festival in May. ${ }^{22}$ Similar to the benevolent Amabie, the blue demon of Ishiyamadera is believed to drive away evil-causing spirits and bring health. A video uploaded onto YouTube by the temple on 10 May 2020 shows images of past ao oni festivals with crowds joining in prayers and worship. The clip ends with images of the 2020 version of the festival with a large statue made of fresh green leaves standing alone in a public park. ${ }^{23}$ Video captions read that during the private ceremony held on 17 May 2020, priests would offer their prayers to the demon and solicit an early end of the pandemic.

In general, a quick trawl through websites of Buddhist temples and Shintō shrines shows that many have been adapting their cultural practices to socially imposed constraints on social gathering and physical contact by swiftly moving online. In this transition, the continuity of production and distribution of temple and shrine goods - whether in the form of online praying, availability of virtual amulets and devotion objects or votive plates-emphasize that praying and worshipping are beyond physical distancing or isolation measures. The sacred intrusions into the privacy of individuals' homes or in public parks through the displacement of symbols and objects rearrange familiar sensations in alternative environments and invite new associations and new engagements with old knowledge.

Indeed, social distancing induced by the new normal in the aftermath of the state of emergency may actually be less disruptive for these widely shared cultural-religious practices which, for many Japanese, are only vaguely anchored in institutionalized religion (Cavaliere 2019a). For established religions, these alternative channels to reach out into the secular may further promote discursive interactions that close gaps with institutionalized religion by allowing regulars and prospective users a broader access to the source of religious authority. The responses by users of the Tōdaiji online streaming website and those attending sutra readings or online shrine visits from their homes show that digitalization or displacement of traditional religions is conducive to creating further access to the sacred, as well as a redesign of symbols, commodi-

22 See https://www.ishiyamadera.or.jp/guide/event/aoonimatsuri (accessed 15 June 2020).

23 See https://www.youtube.com/watch?v=mJOyAgVqyfk (accessed 15 June 2020). 
ties and ways to interact with religion. Although socio-demographic factors may create a digital divide, the transition is allowing more and more people have access to interactive religious sites, and the result is a further diffusion in the social of the usual exclusive spiritual components that traditional religions provide.

The impact of a widespread use of digital media seems to speed up the process of what Bellah (2011) would call "religious evolution." Along the lines of Bellah's argument, this study acknowledges the importance of looking at adaptations and developments of religious-based cultural practices, beliefs and rituals, since religious evolution "add [s] more capacities" along with more complexity (Bellah 2011: xxiii, xix). Given the exceptional circumstances caused by the pandemic, it is worth considering how religions use those new capacities and "the consequences for the world of daily life" (Bellah 2011: xxii) in terms of de-institutionalized and diffused religious socio-cultural values and resources.

\subsection{New Religions as the New Old? (Re-)embracing Technologies for Religious Practice}

That Japanese new religions movements live in a context of strong mistrust is well-documented (Shimazono 1995; Baffelli and Reader 2012). However, when on 18 February 2020 the news that an individual who worshipped at Shincheonji Church of Jesus in Daegu, South Korea, had been identified as the "Patient 31 "24_and thus thought to have caused the rapid rise in cases in the country-Japanese new religions felt tension rise. The case of the South Korean church produced a media-driven sense of urgency and pressure on any religious community and organization in Japan to respond promptly by avoiding collective worship and implementing social distancing.

Indeed, although new religious movements are still the target of intense scrutiny, the pandemic affected the customary thought-styles so that there was no longer any distinction between new trusted or suspicious religious communities, exclusive in-group worship or popular new religions' churches of any type, as they were all perceived as equally potentially harmful and complicit in the most daunting global health crisis of our time. As it happens, in a kind of historical recourse, Japanese tabloids started looking at some new religions such as Sōka Gakkai and Kōfuku no Kagaku 幸福の科学 in order to detect any misstep. ${ }^{25}$ McLaughlin (2020) discusses how Kōfuku no Kagaku remarkably corroborated media's expectations by defying self-restraint orders in order

See https://graphics.reuters.com/CHINA-HEALTH-SOUTHKOREA-CLUSTERS/o10oB5 $\mathrm{G}_{3}$ ${ }_{3} \mathrm{SB} /$ index.html (accessed 21 March 2020).

25 See https://president.jp/articles/-/34141 (accessed 2 April 2020). 
to perform "[Okawa Ryūhō's] signature ritual practice as the most effective means of eliminating the disease" (McLaughlin 2020: 6). By contrast, most new religious organizations had already responded to the call of self-restraint and social distancing in mid-February by shutting their doors, cancelling collective worship and rituals thereafter, and swiftly shifting all meetings and prayers online via Line, Zoom and other such platforms (McLaughlin 2020: 6).

Following the suspension of all activities at their centres at the end of February, on 6 March 2020 Shinnyoen circulated a message via the intraorganizational SNS portal with instructions for weekly online meetings to replace their at-home shūkai 集会 (study groups), along with a message from their leader Itō Shinjō 伊藤真乗 in response to the Covid-19 situation. ${ }^{26}$ On 20 February 2020 Risshō kōseikai informed its affiliates that all ceremonies and worship activities would be cancelled and that they would receive printed material with instructions on online worship and seminars. ${ }^{27}$ Starting 1 March, Tenrikyō, one of the oldest new religions, gradually moved to a complete suspension of all of its activities, including its disaster training activities and the various seminars sponsored by Tenrikyō Saigai Kyūen Hinokishin Tai 天理教災 害救援ひのきしん隊 (Tenrikyō Disaster Relief Hinokishin Corps), as well as the meetings and children's activities of the Tenrikyō Sato-oya Renmei 天理教里 親連盟 (Tenrikyō Foster Parent Association).

Similarly, on 4 March 2020, GLA (God Light Association), a religious movement founded in Tokyo in 1969, announced that all meetings and events were going to be held remotely thereafter (information from an email communication with Yoriko, 46, GLA administrative staff and adherent). With the mounting urgency of social distancing measures in late February, the organization's website was swiftly redesigned to feature highly visible top banners that linked to live streamed events and recorded seminars and workshops. Each head of local GLA terminals (the equivalent of local churches in GLA language) immediately informed their community of affiliates of new online procedures and material. GLA members were little troubled by the transition, since for the past ten years, the organization has been using digital technology to live stream its seminars, workshops and training classes to its members nationwide. Its leader, Takahashi Keiko 高橋桂子, has developed refined leadership and presentation skills to reach her broadcast membership. A well-developed intra-

26 Available at https://www.shinnyo-en.or.jp/\#pickup (accessed 29 May 2020).

27 See https://www.kosei-kai.or.jp/Covidi9/\%E6\%96\%B०\%E5\%9E\%8B\%E3\%82\%B3\%Е3 \%83\%AD\%Е3\%83\%8А\%Е3\%82\%A6\%Е3\%82\%A4\%Е3\%83\%AB\%Е3\%82\%B9\%ЕF\% BC\%88Covid-19\%EF\%BC\%89\%Е3\%81\%B8\%Е3\%81\%AE\%Е6\% \%Е3\%81\%AE $\% \mathrm{E}_{5} \% \mathrm{AF} \% \mathrm{BE} \% \mathrm{E}_{5} \% \mathrm{BF} \% 9 \mathrm{C} /($ accessed 23 May 2020). 
organizational SNS system tested during the Great East Japan Earthquake in 2011 and during the Kumamoto earthquake in 2016 allows swift communications between the headquarters, its branches and its members, thus easing the coordination and the crisis management in case of emergency (Cavaliere 2019c).

By the end of February, the United Church of Christ of Japan, the largest Protestant denomination in Japan, had already cancelled masses, weekly services, Saturday schools, commemorations and wedding ceremonies. ${ }^{28}$ With religious leaders and membership not as accustomed to technology as those in GLA, the shift of Christian denominations to digital technology was slower initially. For instance, the pastor of the Protestant Minō Grace Church in northern Osaka needed to explain to adherents about using Line groups and Zoom, and he had to adjust to the novel online performance of mass and sermons, as he had never had to consider that before.

The Roman Catholic Church in Japan similarly struggled to transition onto a full online modality. Yet, by mid-March, all churchgoers of Minō Catholic Church (northern Osaka) had embraced digital technology such as Line to share and comment on the weekly passages of the Gospel and information about the church services. Despite his initial reluctance, the pastor of the Church quickly managed to enter a comfort zone with recording and uploading his sermons onto YouTube and established a routine for his parishioners to assist the Zoom-based Sunday services. By the end of March 2020, the Church and its members were ready to celebrate some of the most important religious holidays and rituals for Christians: Lent, the Holy Week Procession and Easter, which were performed online between March and early April with no disruption. "I like attending such important rituals from home, it gives more intimacy to my belief” (uchi no shinkō e shitashimi fukai 内の信仰一親しみ深い) commented Satsuko (45), a member of Minō Catholic Church. "One thing I missed the most during the Holy Week procession was the fragrance of the incense that the priest uses in front each Station of the Cross" she added (phone conversation held on 12 April 2020).

As the Holy Week progressed, the church's online worship services became more ambitious, using multiple cameras, pre-recorded portions, and some excerpts of sermons by the Pope sourced from the Vatican website. In transitioning to online services, the church opted to maintain the same format as their face-to-face worship service. This included music - two members of

28 Information collected by the author between March and May 2020 from respondents living in Minō city, northern Osaka. 
the choir and one piano player-and three lay volunteers greeting the online congregation and reading the Gospel passage for the day. Over the course of the Holy Week, the production of the services became more complex, including exterior shots and incorporating children's messages from members who recorded it from their homes. It was a notable change when contrasted with the few pictures and mono-camera recordings of some church services from before the state of emergency.

As it happens, the Catholic and Protestant churches and their members' initial unfamiliarity with digital cameras, microphones and sNs posed less of a challenge than they expected when they moved their religious services online. While the structures and the substance of the practices and the ways to relate to the transcendence do not seem to have been altered much, the forced digital shift have markedly changed the way individuals interact with institutions who hold authority over the transcendence. Results of this investigation show that online worship allows and encourages more engagement and interaction with the religious authority than would otherwise take place in a typical face-toface worship. In the case of the Minō Catholic Church, for example, during the typical passing of the peace in a mass, participants would usually shake hands with others seated near them. During the online service, all members greeted one another typing "peace," and using the reaction and chat features provided by Zoom - thumbs up and chat - to express their approval, along with short messages: ohisashiburi desu (it's been a long time); kinō otsukaresama deshita (thank you for yesterday). These conversation features were used throughout the service to communicate appreciation of a song or an idea expressed in a sermon. In a face-to-face situation, members would never talk or interrupt a sermon. With worship online, members were more actively engaged, typing their approval and responding to one another's comments and asking questions about the priest's sermon. Affiliates' active participation seems to challenge religious institutions to change in a more fundamental way, whereas hierarchies and ministers must be ready to adjust to the increased autonomy that online worship offers to individuals. This, in turns, seems to generate more nuanced social meanings of authenticity, authority, and community.

What these findings show is that while the digital shift was easier for some newer religious groups whose usage of digital technology was already the norm, the reverberation of the shift to online worship has enriched religious institutions of new ways to relate to individuals. They also identify a difference between those new religions that already had some familiarity with information technology and the two Christian denominations that are still more oriented around in-person shared rituals, symbols, sacred sites, and collective devotion. Although in-person religious gathering, worship and religious-based 
collective practices are wished for and expected to resume at some point, they will have to respond to the new normal and embrace its safety measures. While the long-term impact of adaptations observed in this study will need more qualitative data to be assessed, findings seem to suggest an increased individuals' ease toward a digitally-mediated interaction with their organization and a degree of acceptance of less embodied practices as part of their everyday rituals and devotion that might be conducive of more inclusive thought styles.

\section{$3 \quad$ Religions' Outward Responses}

\subsection{Religious Organizations Dealing with Threat of the Public Good}

On 27 February 2020, in a first move to contain the rapidly spreading coronavirus disease Covid-19, Japanese Prime Minister Abe Shinzō requested that elementary, junior and senior high schools nationwide close from 2 March through the end of their spring break, which typically finishes in early April, forcing many students to study at home during the period (Kantei 2020d). With no alternatives in place, many part-time working mothers were forced to quit their jobs (MIC 2020), while stay-at-home parents (both longstanding and those forced home because of the pandemic) were reaching high level of stress because of the forced constant cohabitation. ${ }^{29}$ The effort to contain the spread was soon perceived as directly affecting families, with government shifting the economic and social burden of containment to them. The government responded on 17 April with the decision to distribute a special cash payment of 100,000 yen to all citizens and foreign residents of Japan as an economic measure to counter the economic impact of the new coronavirus outbreak (Kantei 2020e). However, since in most cities the application acceptance period began around mid-May-with actual transactions to take place no sooner than June 2020 - families had to absorb most of the consequences of the Covid-19-induced socio-economic crisis.

Given the pressure of an increased economic uncertainty among parents, on 9 March 2020 Tokyo-based Shinnyoen responded by donating a total of 20 million yen to several non-profit organizations around Japan that support parents and children with difficulties. ${ }^{30}$ Since 11 March 2020, the Hyōgo Community

29 See information on the "Kokoro Mental Health Support Agency for Working People" sponsored by the Ministry of Health, Labor and Welfare at https://kokoro.mhlw.go.jp/ etc/coronavirus_info/.See also the NPO Afterschool at https://npoafterschool.org/Covid/ (accessed 23 May 2020).

See https://www.shinnyo-en.or.jp/news/2020/03/20200309.html (accessed 23 May 2020). 
Foundation in Kobe, ${ }^{31}$ one of the recipients of Shinnyoen's financial support, has been providing free meals and an idokoro 居所 (a place to stay) for children of families in need. Ms. Ueno (57), one of the volunteers of the Hyōgo Community Foundation, commented in a phone conversation on 12 April 2020 that:

this Covid-19 situation is making children vulnerable. Given this exceptional school closure, the local government should create places where kids can safely spend time. But public facilities haven't received instructions from the central government yet, so we are trying to compensate.

Given the lack of available public day-cares for working parents, on 9 March 2020, Risshō kōseikai opened to the public its Suginami byōji hoikushistu shīzu 杉並病児保育室シーズ (Suginami Seeds Day-care for Sick Children) in Tokyo. Information about application procedures and fees were provided on the Suginami ward local government's webpage. ${ }^{32}$

With the number of infected cases on the rise since early May 2020 and the news of health systems around the world at a tipping point, the Japanese government started feeling pressure over its healthcare management. Due to the shortage of protective gear for medical workers, on 14 April Osaka Governor, Yoshimura Hirofumi 吉村洋文, asked the population to donate unused raincoats to be utilized as alternative protective equipment by doctors and nurses treating coronavirus patients. ${ }^{33} \mathrm{On} 15$ April, Osaka-based Shinnyoen responded by donating 500 raincoats they had stocked for earthquake emergency situations. ${ }^{34}$ On 19 May, Sōka Gakkai made a donation of 20 million yen to Tokyo and Osaka prefectures and 10 million yen to the other six prefectures with the highest number of infections. ${ }^{35}$ The donation was aimed at supporting emergency medical costs incurred by the local governments in response to the Covid-19 public health emergency.

Japanese new religions and Christian denominations are not new to donations and other contributions to the local community, and are capable of generating and distributing conspicuous human and physical resources for the sake of the public good (Cavaliere 2015; 2018: 93-97). Given their long-running social

\footnotetext{
31 See https://hyogo.communityfund.jp/\%E6\%9C\%AA\%E5\%88\%86\%E9\%A1\%9E/2O2O/ 03/11/3208/ (accessed 23 May 2020).

32 See https://www.city.suginami.tokyo.jp/shisetsu/kosodate/byougo/1019451.html (accessed 29 March 2020).

33 See https://www.youtube.com/watch?v=zvEiAQr92JI (accessed 15 June 2020).

34 https://www.shinnyo-en.or.jp/news/2020/04/20200415.html (accessed 15 June 2020).

35 See https://www.sokanet.jp/topics/2020-05-19-16348.html accessed May 20th 2020 (accessed 23 May 2020).
} 
contribution activities for the homeless and disadvantaged people, the Roman Catholic Churches in both Tokyo and Osaka mobilized their formal and informal networks to establish counselling and support services for people in need because of the coronavirus pandemic. In Tokyo, services were provided through cooperation with several local NPO s and associations, ${ }^{36}$ while in Osaka, information and support was offered by Sinapis Social Services Association, which is connected to the Osaka Catholic Church. ${ }^{37}$ With its multilingual helpdesk providing a wide range of information, from contacts and procedures in case of infection by coronavirus to legal consultation about visas due to the Covid-19 related restrictions, the Sinapis Social Services Association has been a valuable site for both Japanese and foreigners in the area.

A report issued on 30 March 2020 by the Seikatsu Konkyō Jiritsu Shien Zenkoku Nettowāku生活困窮者自立支援全国ネットワーク (NPO Life Poor Support Japan), ${ }^{38}$ to which Osaka Catholic Church also contributes with donations and volunteer work, addressed the situation of the "net café refugees" (Allison 2012) in Tokyo and Osaka areas who lost their temporary lodgings because of the state of emergency. In the case of a disaster, temples, churches and shrines can offer temporary housing to people who have nowhere to live (Cavaliere 2019c). According to Matsuko (45, Catholic, phone conversation held on 28 March 2020), after the Great East Japan Earthquake in 2011, the local branch of the NPO Life Poor Support Japan in Miyagi Prefecture mobilized their resources and human capital to support both evacuees or homeless people in the disaster-hit area in Tōhoku. They coordinated with other organizations and relied on their Catholic volunteers for their know-how in evacuation support activities. However, the pandemic itself had a much more disruptive impact on the voluntary sector too. Matsuko said that

we were able to mobilize resources and help people even during a disaster of that [Great East Japan Earthquake] scale. However, this time we feel we cannot act concretely as we were hit by an earthquake. In order to prevent the spread of infection, such kind of support is not possible. I'm losing motivation (yaru kiga nakunatte kita やる気がなくなってきた).

36 See https://tokyo.catholic.jp/wp-content/uploads/2020/o5/@onayami_outline.pdf (accessed 12 May 2020).

37 See https://sinapis.osaka.catholic.jp/ (accessed 28 April 2020).

38 See https://www.life-poor-support-japan.net/\%E5\%9B\%Bo\%E7\%AA\%AE\%E8\%80\%85 \%E6\%94\%AF\%E6\%8F\%B4\%E5\%85\%A8\%Е5\%9B\%BD\%Е3\%83\%8D\%Е3\%83\%83\%Е $3 \% 83 \% 88 \% \mathrm{E}_{3} \% 81 \%$ AE$\% \mathrm{E}_{5} \% \mathrm{~A}_{4} \% \mathrm{~A}_{7} \% \mathrm{E}_{4} \% \mathrm{BC} \% 9 \mathrm{~A}-\% \mathrm{E}_{7} \% \mathrm{A \circ} \% 94 \% \mathrm{E}_{4} \% \mathrm{BF} \%$ AE$\%$ E6 $\% 83 \% 85 \%$ E $\%$ A०\%B1/, pp. 30-58 (accessed 2 June 2020). 
In Osaka, out of the four thousand requests the NPO Life Poor Support Japan received since the beginning of March 2020, the organization was only able to provide five hundred people with temporary housing (information collected by phone on 28 March 2020). "We are worried that the number of people losing jobs and who are forced to live under the poverty line will increase because of the pandemic. We will be able to offer them food, but not a place to stay" commented Matsuko. As the coronavirus continues to negatively impact people, especially the most socially vulnerable, religious communities become social stakeholders that can take some concrete measures. However, because of the nature of the pandemic, Catholic volunteer groups in Osaka have been forced to downscale the regular volunteer activities for the homeless and jobless they usually carry out. Matsuko concluded that

this is not because we are worried about the spread of the infection, but because of the tension and the danger we feel when we are on the street. Homeless people rely on collecting and selling recyclable stuff, empty cans and paper, as a form of minimum income. Under the state of emergency, with shops and companies closed down, they are left with no income and this can make them turn to crime.

\subsection{Religious Organizations Dealing with Perceived Disaster Risk}

In a country prone to natural disasters, collective thought-styles are largely constructed upon memories and experiences of such events. These are perceived as the benchmark events against which any emergency situation is measured. Building on past experiences, Japan has developed systems of prevention, response and reconstruction increasingly attentive to the containment of risk and education of the population to prevent and manage various emergencies.

Nine years after the Great East Japan Earthquake, tsunami and nuclear disaster, and four years since an earthquake of 7.0 magnitude hit Kumamoto, the coronavirus outbreak in 2020 shook the foundation of Japan's internationally praised Disaster Risk Reduction (DRR) management. The school closures during the Covid-19 outbreak exposed a new facet of vulnerability due to lack of preparedness measures. "What if a major flood or a powerful earthquake strikes Japan before the outbreak can be contained?" commented Yuriko (36, GLA) in a conversation over Zoom on 12 March 202O. Although the DRR and response measures have improved each time a major catastrophe struck, the pandemic is challenging most processes envisaged in the "Japan DRR model," including the essential role played by schools during a disaster evacuation. Schools in Japan are seen as vital for risk containment, as they provide resilient infrastruc- 
ture to the community, and many of them are designated evacuation centres. However, the Covid-19 pandemic required new protocols and more elaborate preparations to respond to social distancing and prevent a major outbreak during the emergency. Full school closure, along with the compromised reliability on the DRR plan, brutally challenged the collective thought-styles and the shared understanding that enables people in Japan to carry out resilient collective practices in order to respond to a disaster and cope with their vulnerability. As Douglas suggests (1994: 79), such understanding is both factual and normative in that it constitutes a sense of mutual expectations people have from institutions and vice versa.

The pandemic situation critically posed a pressing demand on reformulating the disaster-response-related cultural patterns in "new normal" terms. With DRR government agencies hindered by the pandemic and unable to promptly provide official guidelines, some religious organizations moved forward to anticipate future restrictions in emergency shelters that would facilitate disaster response and population's resilience. In a phone conversation on $28 \mathrm{March}$ 2020, Tsuji, a 38-year-old member of Sōka Gakkai, commented regarding the large earthquake-proof buildings and the level of disaster response preparedness of his religious organization that could adequately respond to an emergency during the pandemic:

The Sōka Bunka Center of Toyonaka [northern Osaka] already has masks, sanitizers, emergency toilets, and tents in stock. It could provide immediate shelter to the local community during the pandemic. Although the acceptance rate may be lower than in other situations because of social distancing measures, the facility is well equipped to implement the ${ }_{3} \mathrm{Cs}$ as needed.

The new disaster evacuation plan (DIL 2O2O) establishes using partitions made of cardboard or other materials to keep each individual or group of evacuees at least two meters apart from each other. It also requires each evacuation shelter to set up special isolation units (tents) for evacuees who are feverish. Tsuneo (61), head of the local Tenrikyō Toyotomi Church in Toyonaka (Osaka Prefecture) and a member of the Tenrikyō Disaster Relief Hinokishin Corps, said that:

The number of evacuees that each school or government-managed centre can accommodate will be halved, at least. So the government is considering directing evacuees to the home of a family member or neighbour that isn't damaged, rather than to an official evacuation centre set up in a school or public facility. We are advising all our local churches to prepare 
to accommodate a number of evacuees in case of an emergency (conversation held on 5 June 2020).

Many of the Tenrikyō local churches are private homes that members make available for the local Tenrikyō community during their weekly meetings and prayers. With the government acknowledging that help from outside entities such as local residents' associations and other organizations may be necessary to run more facilities as evacuation centres, Tenrikyō in northern Osaka responded by "buying 850 camping tents, each 2.7 square meters and 1.7 meters high. These will be distributed to our Tenrikyō local churches in northern Osaka and will be made available for both members and non-members" stated Tsuneo. He added that the organization was also buying face masks, disinfectant and body thermometers to distribute to members so that they can include them in their emergency pack.

Official disaster response capacity seems to have reached its lowest levels since the Great East Japan Earthquake, forcing the government to ease its Disaster Risk Reduction protocol and allow for non-public facilities and partnerships to respond to the pandemic. A similar process was seen in the aftermath of the triple disaster in 2011, with several temples, shrines and other religious communities' facilities designated to become an emergency shelter in the event of a large earthquake (Inaba 2020). This time, the handling of a prospective disaster during the pandemic called for official and unofficial collaborations between the local government and local actors down to individual citizens before the event has actually happened. Although unofficial, religious organizations' disaster preparation and response during the Covid-19 situation has been contributing to risk management, thus becoming a source of resilience during the crisis. The involvement of these local actors has a significant impact because the appeals come from within religious communities and the responses are tailored around local needs, ensuring that resources are efficiently allocated. The fact that more and more temples, shrines, churches and new religions-related facilities and private homes will accommodate evacuees who might not have explicit interest in them could challenge the idea of liminal religious communities that stand on the threshold of their socio-cultural context. Established religions in Japan do not set symbolic boundaries between believers and nonbelievers (Cavaliere 2019a: 16) and although new religions usually require exclusive membership, many members of new religions have developed more syncretic and non-committal modes of religious belonging (Cavaliere 2019a: 3). In a religious-cultural environment that nurtures liminality, so-called mushūkyō members of society may well fluctuate toward a less liminal orientation while embracing neither the organized religions nor commit to a denial of religion. 
In conclusion, although it is not possible at present to sum up the diversity of responses enacted by religious communities in Japan, the prompt response of many religious communities during the pandemic as documented in this study seems to have been more beneficial than harmful, as it can improve the way a community prepares for, responds to, and recovers from crisis and disasters.

\section{4 \\ Discussion}

While demons of the setsubun festival represent evil spirits, some folkloric entities in the world of the $y \bar{o} k a i$, such as Amabie, possess benevolent powers. In both cases, large numbers of people are willing to invest emotionally and practically in these beliefs to mitigate their worries caused by the threat of the Covid-19 pandemic. From a sociological perspective, the two examples discussed in the introductory section demonstrate that there is a diffused and rooted belief among the population in collective rituals framed upon old folk beliefs. These beliefs help them cope with the risk-imbued situation of korona$k a$, the "coronavirus disaster."

As it happens, ghost stories and spirit appearances tend to proliferate around the time a disaster hits, as was seen in the aftermath of the March 2011 triple disaster in Tōhoku and Fukushima (Horie 2016) and Kumamoto earthquake (Cavaliere 2019a: 9-10). Similarly, the cases of setsubun and Amabie have highlighted the existence of a shared cultural framework and related cultural rituals that play a significant role in individuals' everyday life in that they embody a relationship to risk and modalities to contain it. These case studies also reveal individuals' agency and capacity to adjust those established modalities to newer challenges and types of vulnerability. These social phenomena are of special interest in that they configure innovative thought-styles through ritualized and affective repertoires of actions that are relevant to risk management in the future. "For, as a social animal, man [sic] is a ritual animal" (Douglas 1966: $62)$.

Back in 1974, Berger and his colleagues argued that, even if we are unaware of it, modern technology brings with a "technological consciousness" that is difficult to reconcile with a sense of the sacred (Berger et al. 1974). Building on this idea, British sociologist Bryan R. Wilson (1976) similarly claimed that technology secularizes by reducing the occasions on which people have recourse to religion (Wilson 1976: 88). In contrast, recent scholarship seems to acknowledge that access to religion or spirituality through digital technology holds an innovative character in that religious traditions, practices, and value systems themselves shape the adoption and adaption of such technology (Camp- 
bell 2010; Horsfield and Teusner 2007; Howard 2000). Extending the notion of "third space" (Bhabha 2004), Hoover and Echchaibi (2014) propose that the digital encourages generative encounters between commodities and authenticity, authority and autonomy, individual and community, and tradition and secularity.

In this respect, if we shift the focus from the institutional level-which would reveal a drastic Covid-19-induced drop in in-person collective rituals and worship at temples, shrines and churches - to the lived individual level and individual experiences, findings of this study show that the digital shift does not seem to have reduced people's interest in cultural-religious rituals and goods. Viewers of the virtual image of Tōdaiji's Great Buddha, participants of the online Buddhist monks' sutra reading sessions, or consumers of Onoterusaki Jinja's digital ema act as if their new religious imaginaries and expressions were already shared and accepted by their virtual communities as established facts. These Covid-19-induced spiritual and religious third spaces in the digital realm can thus be significant performative sites where not only unitary and formal structures of religious knowledge and practice can be revised and transformed, but also social spaces in which people self-consciously imagine, practice, make, and experience meanings of the sacred.

The displacement of the Ishiyamadera's blue demon from the inside of the temple precinct to the nearby park also creates a third space, an intersection of public and religious space, of sacred and profane that is habitable by devotees, occasional temple-goers and the non-religious alike. It is interesting to note how such spaces and places become imbued with heightened emotional and ritual significance and related thought-styles that have powerful effects in elevating or suppressing perception of risk. Japan is not new to these cultural-religious intersections, as can be seen in a few key examples: the numerous apotropaic rituals people - most of them self-identifying as mush $\bar{u} k y \bar{o}$ - perform in temples and shrines during the new years' visit and throughout the year; the usual reverence to the ubiquitous Jizo 地蔵 statues (the bodhisattva protector of the children); and the diffused usage of amulets (omamori), purification rituals and healing practices. These are practices that stand within the intersection between the subjective and the social, the sacred and the profane, which already belong to the thought-styles of the majority of the population. Thus, this study suggests that the digitally mediated disembodied worship styles might be easily absorbed into such diffused cultural-religious ground, producing newer modalities and thought-styles that are conducive of stability and coherence.

Building on these premises, qualitative observations of this study inform us of interesting variances in religious institutional responses. Firstly, whereas 
the pandemic is offering established religions potential for regeneration and renewal, Japanese new religions have shown little need to transform. Given the socio-historical and constitutional circumstances that have imposed a marginal status on new religions in Japan, their established capacity of riding the digital wave to by-pass public visibility is not surprising. Most new religions' leaders and their members are not new to rituals and services streamed online, prayers and individual member's comments posted on SNS, and video links and texts shared on smartphones. Because of their relatively unproblematic transition as compared to, for example, Christian denominations or less outfitted Buddhist temples and Shintō shrines, one would suggest that contemporary Japanese new religious movements are becoming the new old. If we define 'new' as something that is innovative as opposed to that which is traditional and holds an explicit, self-conscious commitment to be modern, then the rapid shift online of many shrines and temples like Tōdaiji and Katori Jinja is a remarkable sign of the established religions' capacity of modification and innovation.

One can contend that religious innovations being observed here were born largely out of necessity due to the community constraints and social-distancing policies. How will these online communities exist when and if the situation goes back to the former face-to-face, embodied type of worship? What is clear from the findings of this study is that these established religious institutions have offered access to users' communities inhabited by a wider range of inperson worshippers, online users, active believers and mushūkyō consumers, all sharing an unprecedented degree of freedom on what to believe and what virtual sacred goods to consume. The transition to virtual worship-while abrupt and forced on temples and shrines that have long relied almost exclusively on embodied rituals - allowed these religious communities to reach a wider audience by extending and reinterpreting existing practices. In this respect, if we take Durkheim's notion that "religion must be an eminently collective thing" (1995[1912]: 44), then the Covid-19-induced altered Buddhist and Shintō social spaces constitute more innovative, more inclusive and popular religious communities than the new religions' ones.

Secondly, and relating to above, the pandemic seems to have produced new values and expectations for what cultural-religious-related practices religious institutions should provide, which are expected to be more inclusive, both symbolically and emotionally. Temples, shrines and churches of both established and new religions have shown a capacity of recreating familiar sensations in virtual environments, which has invited new associations and new engagements with old knowledge. The online interactions and the altered hierarchies which are reproduced through these new modalities may have impor- 
tant implications for established thought-styles and categories, which become woven into the more immaterial and ephemeral ontology of the cyberspace. Established religions with their temples, shrines and churches have now time to consider what this rapid transformation means for them as a physical local community and how to exist as an online, boundary-crossing community as well.

With the state of emergency lifted, temples and shrines are cautiously resuming their in-person embodied activities. However, it is suggested here that the digital move and shift from embodied to disembodied religious practice holds a potential to continue beyond the ease in social restrictions: as the Japanese government recommends, the 3 Cs should become the 'new normal' in every aspect of people's life, and so may socio-cultural practices imbued of religious acts, values and beliefs. In Japan, many rituals and beliefs are already embodied and practiced beyond faith communities and play a central function in transmitting religious culture regardless individuals' degree of involvement in religious activities. The shift from offline to online has challenged religious leaders' fundamental beliefs regarding embodiment and disembodiment in religious practice, while consumers of such religious socio-culture might see religion as more an everyday occurrence than they might have thought before. Here lies the potential development of those diffused thought-styles that are experienced as an alignment "between institutions, beliefs, and actions [that] will reinforce stability" (Douglas 1994: 79).

A third important consideration concerns the social role of religious institutions, in terms of social acceptance and public status. Rather than potential harmful communities, the early implementation of social distancing and self-restraint measures of the religious organizations discussed here worked as intensifiers of resilient responses. Religious organizations also largely anticipated the government declaration of state of emergency: they helped reduce the spread of the infection and reinforced healthy social behaviours to fight against Covid-19 among their affiliates. From the time axis perspective, findings show that those organizations responded appropriately at a time when the government was still seeking to identify how to deal with a potential critical level of pandemic. From the agency axis perspective, cancelling worship and events at early stage allowed organizations to implement exceptional measures calmly and fully, while reducing the emotional impact on their members.

In Durkheimian terms, the moral and practical capacity of these organizations' organic solidarity - coordinating and reducing the complexity of forms of actions in managing the crisis-contributed to containing the impact of the pandemic by strengthening resolve and motivating action. Both GLA and Sōka Gakkai respondents of this study agreed their organizations' early deci- 
sions regarding cancellations and bans from entering the religious buildings were perceived as "necessary preparation for a not-yet-known situation" (mada jūbunna jōhō ga tarite inai jōkyō de ari, junbi shite oku koto ga jūyō desu ま だ十分な情報が足りていない状況であり準備しておくことが重要です; Mutsuko, 56, Sōka Gakkai). This claim explains respondents' perception of vulnerability, which is concatenated to the lack of possible mechanisms or conditions that undermine individuals' capacity to respond to the current pandemic. In such circumstances, being able to rely on a religious community, receive clear guidelines and have rapid access to resources and services can quite dramatically reduce such vulnerability. Building upon Douglas' insights on risk and uncertainty along with a focus on strategies to combat these issues by looking at specific micro and macro capacities, this study has shown how religious communities have pro-actively contributed to the management of the crisis. This makes religious institutions into moral competitors to the local authorities and government agencies as well as socially desirable institutions caring for the public good.

Given the general skepticism around state inference in religious affairs and the lingering concerns about new religious organizations as mentioned above, their contribution is still perceived as an unwanted incursion in the public sphere. Still, past disasters have demonstrated that the involvement of new religious organizations employing their resources and networks may bring new sets of actors and perspectives to the thought-styles that can contribute to resilience-making: they can provide crucial logistics, information and resources to supplement or improve the extant government-based responses. While a government may quantify the risk to society by assessing available resources to cope with the crisis at the macro-level, the perceived risk to groups and individuals varies as does their perceived potentials and resources to respond directly to the crisis. Douglas pointed out that the perception of risk isn't uniformly distributed, but depends on one's worldview, which not only shapes risk perceptions, but also has practical implications (Douglas 1994: 50).

What is clear from respondents' accounts in this study is that their perception of risk from the pandemic and their capacity for crisis management are commensurate to their religious community potential to reach them out and care for them. The 'new normal' created by Covid-19 means that individuals have had to adjust to new types of risk and vulnerabilities. Findings of this study show that, in these circumstances, religious institutions have continued to imagine new ways to respond to individuals' sense of risk by offering new modalities of gathering, opportunities for relationship building, ways of expressing their devotion and safe places to use in case of a disaster, all of which meet the new social conditions and demands. 
This paper has attempted to track the impact and outcomes of the Covid-19 driven religious socio-cultural shifts being experienced in Japan during the time span of February and June 2020. Guided by a crisis approach that looks into threat, uncertainty and urgency as components for a critical analysis of a situation, the study explored the inward and outward responses both at macroand micro-level that some Japanese religious institutions and their members have enacted to cope with perceived risk. The investigation interpreted those crisis components looking at reformulations and redesigning of what Douglas (1994) calls "thought-styles" that are conducive of cohesion and stability. Findings have shown that established and new religions alike swiftly responded to Covid-19-induced distancing measures by embracing digital technology to continue their core function of cohesion-providers for their social and spiritual communities.

Established religious institutions showed the most interesting development, with a shift from embodied to disembodied religious practices that hold a potential to continue beyond the ease in social restrictions. While temples, shrines and churches in Japan have dramatically downsized or cancelled religious-related collective events, ceremonies and rituals, religious communities have found alternative spaces and digital modalities to reformulate cosmological beliefs and collective religious-cultural practices. In so doing, they are providing the needed repertoires of possible answers (Douglas 1994: 5) that help develop a collective resilient capacity of neutralizing worries and threat. This examination of the various adjustments made by religious institutions and their members' thought-styles has revealed adaptations of such collective repertoires and the way such alternatives have helped communities to enact resilient responses. This paper focused on those Durkheimian sociocultural rituals that construct social interactions between religious institutions and affiliates and how these opened up unforeseen "windows of opportunity" (Kingdon 1984) for individuals and their institutions. With their level of disaster preparedness as well as human and physical resources available to mobilize, new religions might display their potential role as public providers of community resilience.

The observations and narratives reported in this paper have highlighted the moral urgency that religious organizations, as social institutions, have felt to take action and provide both spiritual and practical guidance to regular and occasional members as well as how they had to adapt to new ways to connect, celebrate holidays and worship through various internet resources. It also showed a potential shift from a collective embodied to a more subjective medi- 
ated experience driven by digital technology. With individuals allowed a closer glance at the source of religious institutions' authority without the need to approach such authority, this study indicates that the Covid-19-induced situation buffers diffused religious-cultural values and ideas. The newer diffused religious-cultural framework in Japan might be once again conducive of shared moral values that generate cohesion over institutional hierarchy, and could provide ways of stabilizing cultural forms that provide resilience.

\section{References}

Arjen Boin, Paul't Hart and Sanneke Kuipers. 2007. “The Crisis Approach.” In Handbook of Disaster Research, eds. Havidán Rodríguez, William Donner, Joseph E. Trainor, New York: Springer, 23-38.

Allison, Anne. 2012. "Ordinary Refugee: Social Precarity and Soul in 21st Century Japan." Anthropological Quarterly 85(2): 345-370.

Baffelli, Erica, and Reader, Ian. 2012. "Editors' Introduction-Impact and Ramifications: The Aftermath of the Aum Affair in the Japanese Religious Context." Japanese Journal of Religious Studies 39: 1-28.

Bhabha, Homi K. 2004. The Location of Culture. Abingdon: Routledge.

Bellah, Robert N. 2011. Religious in Human Evolution: From the Paleolithic to the Axial Age. Cambridge MA: Harvard University Press.

Berger, Peter. L., Berger, Brigitte and Kellner, Hensfried. 1974. The Homeless Mind. Harmondsworth, UK: Penguin.

Campbell, Heidi. 2010. When Religion Meets New Media. Oxon: Routledge.

Cavaliere, Paola. 2015. Promising Practices: Women Volunteers in Japanese Religious Civil Society. Leiden: Brill.

Cavaliere, Paola. 2018. "Mothers and Moral Activists: Observing Women in Religious Informal Volunteering in Japan." Journal of Religion in Japan 7(2): 93-125. https://doi .org/10.1163/22118349-00702003.

Cavaliere, Paola. 2019a. "Women between Religion and Spirituality: Observing Religious Experience in Everyday Japanese Life." Religions 10: 2-21. https://doi.org/10 .3390/rel10060377 (accessed 29 June 2020).

Cavaliere, Paola. 2019b. "Female Leadership in Contemporary Japanese Religious Organizations: The Case of Shinnyoen." Osaka Human Sciences 5: 139-156. http://hdl .handle.net/11094/71751 (accessed 29 June 2020).

Cavaliere, Paola. 2019c. "Building Resilience: The Role of Women in Faith-based Disaster Response to the 2016 Kumamoto Earthquakes." Paper presented at the British Association for Japanese Studies, University of Edinburgh, 6 September.

Davie, Grace. 2007. "Vicarious Religion: A Methodological Challenge." In Everyday Reli- 
gion: Observing Modern Religious Lives, ed. Nancy T. Ammerman, Oxford: Oxford University Press, 21-35.

Davie, Grace. 2010. “Vicarious Religion: A Response." Journal of Contemporary Religion 25(2): 261-266.

Durkheim, Emile. 1995 [1912]. The Elementary Forms of Religious Life. New York: Free Press.

DIL (Disaster Information Laboratory). 2020. "Covid-19: Saigai hinan ni kansuru jōhōshūyaku saito beta puran ni tsuite.” Covid-19 災害避難に関する情報集約サイトベ タプランについて. https://dil.bosai.go.jp/disaster/Covid19/index.html (accessed 15 June 2020).

Douglas, Mary. 1966. Purity and Danger: An Analysis of Concepts of Pollution and Taboo. London: Routledge \& Kegan Paul.

Douglas, Mary. 1994. Risk and Blame: Essays in Cultural Theory. London: Routledge.

Fritz, Charles E. 1961. "Disaster." In Contemporary Social Problems, eds. Merton, Robert and Nesbit, Robert, New York: Harcourt Publishers, 651-694.

Hoover, Steward M. and Echchaibi, Nabil. 2014. "The Third Spaces of Digital Religion. Discussion Paper." The Center for Media, Religion, and Culture. https://www.colorado .edu/cmrc/2016/og/o1/third-spaces-digital-religion-draft (accessed 20 May 2020).

Horie, Norichika. 2016. "Continuing Bonds in the Tōhoku Disaster Area: Locating the Destinations of Spirits." Journal of Religion in Japan 5(2-3): 199-226.

Horsfield, Peter and Teusner, Paul. 2007. "A Mediated Religion: Historical Perspectives on Christianity and the Internet." Studies in World Christianity 13(3): 278-295.

Howard, Robert G. 200o. "On-line Ethnography of Dispensationalist Discourse: Revealed versus Negotiated Truth.” In Religion on the Internet: Research Prospects and Promises, eds. Cowan, Douglas and Hadden, Jeffrey, Amsterdam/London/New York: JAI Press, 225- 248.

Inaba, Keishin 稲場圭信. 2020. Jichitai to shūkyō shisetsu, dantaito no saigai kyōryōku ni kan suru chōsa 自治体と宗教施設団体との災害協力に関する調査 https://note.com/ dr178/n/nd4585315a89b (accessed 28 May 2020).

Kantei 官邸 (Cabinet Office of Japan). 2020a. [Covid-19] Declaration of a State of Emergency in response to the Novel Coronavirus Disease (April 7). https://japan.kantei.go .jp/ongoingtopics/_ooo18.html (accessed 29 May 2020).

Kantei 官邸 (Cabinet Office of Japan). 202ob. [Covid-19] Shingata koronauirusu kansenshō ni kansuru Abe naikaku sōridaijin kishakaikei 新型コロナウイルス感染症に関する 安倍内閣総理大臣記者会計. https://japan.kantei.go.jp/98_abe/statement/202004/ _oooo1.html (accessed 29 May 2020).

Kantei 官邸 (Cabinet Office of Japan). 2020c. Press Conference on the Telephone Conference with the President of the IOC. https://japan.kantei.go.jp/98_abe/actions/202003/ _ooo37.html (accessed 29 May 2020).

Kantei 官邸 (Cabinet Office of Japan). 2020d. 15th Meeting of the Novel Coronavirus 
Response Headquarters. https://japan.kantei.go.jp/98_abe/actions/202002/_ooo42 .html (accessed 13 May 2020).

Kantei 官邸 (Cabinet Office of Japan). 2020e. Information on Support Measures Related to Covid-19. http://japan.kantei.go.jp/ongoingtopics/coronavirus_info_e.html\#c5 (accessed 23 May 2020).

Kingdon, John. 1984. Agendas, Alternatives and Public Policies. Boston, MA: Little, Brown and Co.

McLaughlin, Levi. 2020. "Japanese Religious Responses to Covid-19: A Preliminary Report." Japan Focus 18:1-23.

MHLW (Japanese Ministry of Health, Labor and Welfare). 2020a. Wakamono no kata: Shiranai uchi ni hiromecchau kara 若者の方知らないらちに広めっちやうから. https:// www.mhlw.go.jp/content/109ooooo/ooo620716.jpg (accessed 20 June 2020).

MHLW (Japanese Ministry of Health, Labor and Welfare). 2020b. Hospitalization and Discharge-As of March 15 2020. https://www.mhlw.go.jp/content/10900ooo/ooo61 2510.pdf, (accessed 29 May 2020).

MHLW (Japanese Ministry of Health, Labor and Welfare). 2020c. Basic Policies for Novel Coronavirus Disease Control-Revised on April 7, 2020. https://www.mhlw.go .jp/content/109000oo/ooo620733.pdf (accessed 29 May 2020).

MHLW (Japanese Ministry of Health, Labor and Welfare). 2020d. Update on Covid19 in Japan-April 8th 2020. https://www.mhlw.go.jp/content/1090000o/00o620718 .pdf (accessed 20 June 2020).

MHLW (Japanese Ministry of Health, Labor and Welfare). 2020e. Basic Policies for Novel Coronavirus Disease Control-Revised on May 25th, 2020. https://www.mhlw.go.jp/ stf/seisakunitsuite/bunya/newpage_ooo32.html (accessed 29 May 2020).

MIC (Ministry of Internal Affairs and Communications). 2020. Rōdōryoku chōsa: Kihon shukei 2020nen 5 gatsu 労働力調査基本集計 20 年 5 月. https://www.stat.go.jp/data/ roudou/sokuhou/tsuki/pdf/gaiyou.pdf (accessed 23 May 2020).

NHK Broad Casting Cultural Research Institute. 2019. "Dai 1o kai nihonjin no ishiki chōsa” 第10回日本人の意識調査. https://www.nhk.or.jp/bunken/research/yoron/ pdf/20190107_1.pdf (accessed 5 March 2020).

Shimazono, Susumu. 1995. "New New Religious Movements in This World: Religious Movements in Japan after 1970 and their Beliefs about Salvation." Social Compass 42: 193-205.

wHO (World Health Organization). 2020a. WHO Director-General's Opening Remarks at the Media Briefing on Covid-19—-11 March 2020. https:/www.who.int/dg/speeches/ detail/who-director-general-s-opening-remarks-at-the-media-briefing-on-Covid-19 ---11-march-2020 (accessed 25 June 2020).

wHo (World Health Organization). 2020b. Practical Considerations and Recommendations for Religious Leaders and Faith-based Communities in the Context of Covid-rg. https://www.who.int/publications/i/item/practical-considerations-and-recommen 
dations-for-religious-leaders-and-faith-based-communities-in-the-context-of-Covi d-19 (accessed 25 June 2020).

wHo (World Health Organization). 2020c. Coronavirus Disease 2019 (Covid-19) Situation Report-67. https:/www.who.int/docs/default-source/coronaviruse/situation -reports/20200327-sitrep-67-Covid-19.pdf?sfvrsn=b65f68eb_4 (accessed 25June 2020).

Wilson, Bryan R. 1976. Contemporary Transformations of Religion. Oxford: Oxford University Press. 